\title{
Utilization of Sludge Waste as Fertilizer for Chili Plants: Observed from Technical, Economical Aspects and Farmers' Perceptions
}

\author{
Aditya Arifianto, Agus Budianto
}

Environmental Engineering, Faculty of Civil and Planning Engineering, Institut Teknologi Adhi Tama Surabaya, Arief Rachman Hakim 100 Surabaya, 60117, Indonesia

\begin{abstract}
PT. X was an industrial company that engaged in chicken slaughterhouse and meat processing and its derivatives, with a continuous production process that produced a variety of waste ranging from Liquid, Solid, and others. Moreover, for the type of liquid waste produced by PT. X, was treated with a Wastewater Treatment Plant which was one of the facilities in PT. X. The second stage was to make a comparison between Sludge, chicken manure, and rice husk. Furthermore, there was a variation of the ratio: the first 1: 1: 1 and the second 2: 1: 1 where two were the number of sludge. Application of fertilizers was carried out on chili plants. From the test results, it showed that there was an increase in productivity between $30 \%-42.8 \%$ in chili plants. Therefore, the cost of fertilizing in one crop of chili with compost processed by Sludge IPAl of PT. X was equal to Rp. 1,500 per stem in a single planting period. As for the NPK Mutiara fertilizer, the cost incurred for fertilizing in a single chili planting period was Rp. 4,050, - per stem of chili plants. While the result of the questionnaire towards the attitudes of farmers showed sufficient value, hence, the fertilizer processed by IPAL sludge had a good chance to be accepted by the community, especially chili farmers.
\end{abstract}

Keywords-Chili Plants, Compost, NPK fertilizer, Sludge, WWTP.

\section{INTRODUCTION}

Industrial estates in Indonesia began to multiply and spread in almost all regions. According to data from the Ministry of Industry Performance Achievement (Kemenperin) 2015 - 2017 showed that in the period of 2015 - 2017 successfully built and operated three new industrial zones on Java Island and seven new industrial zones outside of Java and predicted for the next 2 years will growing 6 new industrial areas outside Java in 2019. With the development of the industrial areas in Indonesia, it will surely be followed by the problems that arise from these industrial activities.

The condition of sludge was organic and very smelly. If it was left to stand for days, it would result in smelly and sour odour and could create a very disturbing environment around the factory. The analysis showed that the sludge contained organic N, P and Celements, as well as $\mathrm{Ca}, \mathrm{Mg}, \mathrm{K}, \mathrm{Cu}, \mathrm{Mn}, \mathrm{Zn}$ and $\mathrm{Fe}$ elements which were nutrients needed by plants. However, the $\mathrm{C} / \mathrm{N}$ ratio of the sludge produced was low; thus, it needed to be mixed with organic material which has a high $\mathrm{C}$ content for its utilization to the soil. Husk was a by-product of rice harvest which had high $\mathrm{C}$ levels therefore it could be used as a mixture (bulking agent) in the composting process.

\section{LITERATURE REVIEW}

Waste was basically a material that was excerted from human activities or natural processes that have no or no economic value. It often had negative economic value because the disposal management of it required a relatively large cost. Based on the source, waste was divided into three: natural waste, domestic waste and industrial waste (Murtadho and Said, 1988). Organic sludge originateded from primary and secondary settling tank The sludge from the primary settling tank, called the primary sludge, was a solid precipitate which flown along with the wastewater, while the sludge from the secondary settling tank, called the secondary sludge, was a residual microbial precipitated that was discharged from the Wastewater Treatment Plant. The condition where there was no oxygen in wastewater, could take place optimally at temperatures of $35-500 \mathrm{C}$ with a $\mathrm{pH}$ value of 7.0 to 6.0 that occured during the denitrification process and served to convert nitrates into nitrogen gas (Dawson and Murphy, 1972). On the other hand, composting was a process of decomposition and stabilization of organic matter by microorganisms in a controlled environment with the final result in the form of humus and compost (Simamora and Salundik, 2006). Chili plants (Capsicum frutescens L.) was one of the horticultural crops of 
vegetables which had small fruits with a spicy flavor. Chili plants (Capsicum frutescens L.) had several regional names, such as (in the area of Java) chili japlak, mengkreng, cengis, ceplik, or cempling.

\section{METHOD OF THE STUDY}

Equipment: Mixing materials (containers), Mixer, Gloves, Scales, Sieves, Fertilizer containers .

Materials: Waste sludge (IPAL Sludge), Rice husk. Chicken manure

How to do:

1. Taking a sludge sample
Samples (dried sludge) were taken from WWTP at PT X

2. Sludge sample preparation

The sludge sample was dried on plastic and allowed it to dry. Then, crushed and sieved in a 100 mesh sieve, then weighed as much as $9 \mathrm{~kg}$.

Manufacturing the Fertilizer

1. Preparing tools and materials

2. Making a ratio of 1: $1: 1$ and 2: $1: 1$

3. The process of mixing ingredients

4. Four weeks of composting process

5. Compost was ready to use

\section{DISCUSSION}

The content or characteristics of WWTP sludge by PT. X after conducting the analysis

Table.1: Sludge Characteristic of IPAL by PT. X

\begin{tabular}{|l|l|}
\hline \multicolumn{1}{|c|}{ Characteristic } & \multicolumn{1}{c|}{ Result } \\
\hline Explosive & Not Explosive \\
\hline Flammable & Not Flammable \\
\hline Reactive & Negative \\
\hline Corrosive $(\mathrm{pH} \leq 2.5$ or $\mathrm{pH} \geq 12.5)$ & 5,58 \\
\hline
\end{tabular}

Source: Laboratory Analysis

Table.2.: Sludge Characteristic of IPAL by PT. X compared to Standard Indonesian Compost

\begin{tabular}{|l|c|c|c|c|}
\hline \multirow{2}{*}{ Parameter } & \multirow{2}{*}{ Unit } & \multicolumn{2}{c|}{ Compost Quality Standard } & \multirow{2}{*}{$\begin{array}{c}\text { Initial Sludge } \\
\text { Concentration }\end{array}$} \\
\cline { 3 - 5 } & & Minimum & Maximum & 20,41 \\
\hline Water Content & $(\%)$ & - & 50 & 20 \\
\hline Particle Unit & & 0,55 & 25 & 7,02 \\
\hline pH & & 6,80 & 7,49 & 0,60 \\
\hline Nitrogen & $(\%)$ & 0,40 & $*$ & 20,25 \\
\hline Carbon & $(\%)$ & 9,80 & 32 & 1,52 \\
\hline Phosfor (P2O5) & $(\%)$ & 0,10 & - & 33,75 \\
\hline C/N Rasio & & 10 & 20 & 1,46 \\
\hline Calium (K2O) & $(\%)$ & 0,20 & $*$ & $<0,002$ \\
\hline Arsen & $\mathrm{mg} / \mathrm{kg}$ & $*$ & 13 & $<0,008$ \\
\hline Cadnium (Cd) & $\mathrm{mg} / \mathrm{kg}$ & $*$ & 3 & $<0,002$ \\
\hline Mercury (Hg) & $\mathrm{mg} / \mathrm{kg}$ & $*$ & 0,8 & 2,1 \\
\hline Lead (Pb) & $\mathrm{mg} / \mathrm{kg}$ & $*$ & 150 & 41,36 \\
\hline Zinc (Zn) & $\mathrm{mg} / \mathrm{kg}$ & $*$ & 500 & $<0,002$ \\
\hline Iron (Fe) & $(\%)$ & $*$ & 2,00 & 0,002 \\
\hline Manganese (Mn) & $(\%)$ & $*$ & & \\
\hline
\end{tabular}

Source: Laboratory Analysis

Note: * The value is greater than the maximum unit

Quality standard according to SNI 19-7030-2004 
Table.3: Sludge Characteristic of IPAL by PT. X Compared to Sample A dan Sample B

\begin{tabular}{|c|c|c|c|c|c|}
\hline \multirow[t]{2}{*}{ Parameter } & \multirow[t]{2}{*}{ Unit } & \multicolumn{2}{|c|}{$\begin{array}{c}\text { Compost Quality } \\
\text { Standard }\end{array}$} & \multicolumn{2}{|c|}{ Consentration } \\
\hline & & Minimum & Maximum & Sample A & Sample B \\
\hline Water Content & $(\%)$ & - & 50 & 20,15 & 7,18 \\
\hline Particle Unit & & 0,55 & 25 & 20 & 15 \\
\hline pH & & 6,80 & 7,49 & 7,40 & 7,08 \\
\hline Nitrogen & $(\%)$ & 0,40 & $*$ & 1,20 & 0,76 \\
\hline Carbon & $(\%)$ & 9,80 & 32 & 22,25 & 12,51 \\
\hline Phosfor $\left(\mathrm{P}_{2} \mathrm{O}_{5}\right)$ & $(\%)$ & 0,10 & - & 0,71 & 0,72 \\
\hline C/N Rasio & & 10 & 20 & 26,70 & 16,42 \\
\hline Calium $\left(\mathrm{K}_{2} \mathrm{O}\right)$ & $(\%)$ & 0,20 & $*$ & 0,51 & 0,46 \\
\hline Arsen & $\mathrm{mg} / \mathrm{kg}$ & $*$ & 13 & $<0,002$ & $<0,002$ \\
\hline Cadnium (Cd) & $\mathrm{mg} / \mathrm{kg}$ & $*$ & 3 & $<0,008$ & $<0,008$ \\
\hline Mercury (Hg) & $\mathrm{mg} / \mathrm{kg}$ & $*$ & 0,8 & $<0,002$ & $<0,002$ \\
\hline Lead $(\mathbf{P b})$ & $\mathrm{mg} / \mathrm{kg}$ & $*$ & 150 & 1,98 & 1,5 \\
\hline Zinc (Zn) & $\mathrm{mg} / \mathrm{kg}$ & $*$ & 500 & 40,98 & 40,11 \\
\hline Iron $(\mathrm{Fe})$ & $(\%)$ & $*$ & 2,00 & $<0,002$ & $<0,002$ \\
\hline Manganese (Mn) & $(\%)$ & $*$ & 0,10 & $<0,002$ & $<0,002$ \\
\hline
\end{tabular}

Source: Laboratory Analysis

Note: * The value is greater than the maximum unit

Quality standard according to SNI 19-7030-2004

Sample A with ratio $1: 1: 1$

Sample B with ratio $2: 1: 1$

From these results, it could be seen that compost made with a ratio of 1: 1: 1 did not meet the quality standards for Indonesian compost, because the value of the $\mathrm{C} / \mathrm{N}$ ratio was still above the applicable quality standard. According to Kusumawati, the 2015 ratio of high $\mathrm{C} / \mathrm{N}$ values showed that compost had not been decomposed completely or in other words compost was not yet ripe. Moreover, high $\mathrm{C} / \mathrm{N}$ ratio could be caused by several factors, one of which was composting time and compost made.

From the results of the laboratory tests, it could be concluded that the research would be continued only for the variation of the ratio between sludge: chicken manure: rice husk 2: 1: 1. Because the laboratory test for 1: 1: 1 variation could not fulfill the Indonesian compost standard according to SNI 19-7030-2004. Thus, even if the variation was applied, the results could not be mass produced because they did not meet the required standards

Sludge produced by Compost had a brownish black color characteristic and had a slightly soft texture due to the mixture of chicken manure which was still wet as a mixture in the compost making process.
Application of composting was conducted when the chili plants began to blossom. Before that process, the treatment of chili plants was only done in the form of watering plants every day and cleaning the area around the plant and not to be disturbed by weeds or pests that could interfere with the productivity of chili plants. The composting process was done by making a dose of 100 grams of fertilizer sprinkled on them and buried them with the soil. This was because fertilizers did not easily evaporate and dissolve in rain water. The use of this fertilizer was used only once for 21 days during the productivity period of chili. Because the application of compost which was too much could disturb the balance of nutrients in the soil. (Musnamar, E.I., 2006)

For testing, it was done by comparing the effectiveness of compost fertilizer with the one that had been circulating in the market for the type of fertilizer in chili plants. In this experiment, compost was compared with NPK Mutiara fertilizer. From the test result, it showed that there was an increase in productivity between $30 \%-42.8 \%$ in chili plants with the treatment of adding compost from the results of the utilization of WWTP sludge by PT. X. For the results from both types of fertilizers could be seen in the table below: 
Table.4: Results of Chili Plant with Two Types of Fertilizers

\begin{tabular}{|c|l|c|c|}
\hline \multirow{2}{*}{ No. } & \multirow{2}{*}{ Planting Area } & $\begin{array}{c}\text { Compost Fertilizer } \\
\text { (IPAL Sludge) }\end{array}$ & NPK Mutiara Fertilizer \\
\hline 1. & Area 1 & 130 unit & 100 unit \\
\hline 2. & Area 2 & 150 unit & 105 unit \\
\hline 3. & Area 3 & 125 unit & 90 unit \\
\hline
\end{tabular}

Source: Research result

Analysis of economic aspects was carried out to determine the difference in costs incurred by farmers using NPK Mutiara fertilizer and compost fertilizer from the utilization of WWTP sludge by PT. X, shown in the table below:

Table.5: Comparison of Planting Costs and Planting Results Between NPK Mutiara and Compost Fertilizer on Chili Plants Per Hectar of Land

\begin{tabular}{|c|c|c|c|c|}
\hline Fertilizer Type & Planting Area & Planting Cost (Rupiah) & $\begin{array}{l}\text { Harvesting Yield } \\
\text { (Rupiah) }\end{array}$ & $\begin{array}{l}\text { Deviation Profit } \\
\text { (Rupiah) }\end{array}$ \\
\hline \multirow{4}{*}{ NPK Mutiara } & Area 1 & Rp. 40.500.000,- & Rp. 50.000.000,- & Rp. 9.500.000,- \\
\hline & Area 2 & Rp. 40.500.000,- & Rp. 52.500.000,- & Rp. 12.000.000,- \\
\hline & Area 3 & Rp. 40.500.000,- & Rp. 45.000.000,- & Rp. 4.500.000,- \\
\hline & Average Cost & Rp. 40.500.000,- & Rp. 49.166.700,- & Rp. 8.666.700,- \\
\hline \multirow{4}{*}{$\begin{array}{l}\text { Compost by IPAL } \\
\text { sludge }\end{array}$} & Area 1 & Rp. 21.000.000,- & Rp. 65.000.000,- & Rp. 44.000.000,- \\
\hline & Area 2 & Rp. 21.000.000,- & Rp. 75.000.000,- & Rp. 54.000.000,- \\
\hline & Area 3 & Rp. 21.000.000,- & Rp. 62.500.000,- & Rp. 41.500.000,- \\
\hline & Average Cost & Rp. 21.000.000,- & Rp. 67.500.000,- & Rp. 46.500.000,- \\
\hline \multicolumn{2}{|c|}{$\begin{array}{l}\text { Deviation of NPK Mutiara } \\
\text { \& Compost Fertilizer }\end{array}$} & Rp. $19.500 .000,-$ & Rp. 18.333.300,- & Rp. 37.833.300,- \\
\hline
\end{tabular}

Source: Research result

While the results of the questionnaire towards the attitudes of farmers showed sufficient value, it meant that the fertilizer processed by IPAL sludge had a good chance to be accepted by the community in this case chili farmers. Unsatisfactory results required additional seed inoculation with Rhizobium and phosphobacterin that significantly increased nitrogen and potassium levels (Dutta and Bandyopadhyay, 2009).

Application of a combination of bio-phosphate and phosphorus chemical fertilizers could be a practical and useful method for increasing corn yields and reducing environmental pollution (Khatoon et al., 2011). The use of organic fertilizer of $300 \mathrm{~kg} / \mathrm{ha}$ was a strategy to protect the environment from threats posed by organic waste (Arshad et al., 2008). Fertilizers using biogas residues provided higher yields than NPK and biogas residues which increased soil microbial activity (Abubaker et al., 2012). Bio-organic fertilizer which was a combination of manure compost with antagonistic microorganisms, as well as organic fertilizer was able to prevent plants from wilting and susceptible to disease (Qiu et al., 2012).
Field studies were conducted at Egerton University with two seasons for comparison. In first season, bioslurry fertilizer increased carrot yields $8.8 \%$ and $23.5 \%$ in season 2 . Total dissolved solid of plant roots was $12.7 \%$ higher in season 1 and $13.2 \%$ in season 2 compared to controls. In conclusion, this study recommended $7.8 \mathrm{t} / \mathrm{ha}$ of bioslurry fertilizer to improve yield and quality of carrots (Jeptoo et al., 2013). Bio slurry from the anaerobic process could be used in fish ponds to produce plankton to feed fish, and could be applied to arable land and fertility fields, while biochar from pyrolysis was better used to improve soil on arable land (Orskov et al., 2012).

\section{CONCLUSION}

1. From the results of the analysis that had been carried out on the WWTP sludge by PT. X, it showed that the value for macro $\mathrm{N}$ component was $0.60 \%$, $\mathrm{P}$ was $1.52 \%, \mathrm{~K}$ was $20.25 \%$, and $\mathrm{C} / \mathrm{N}$ ratio was 33.75 . Whereas the $\mathrm{C} / \mathrm{N}$ ratio value exceeded the compost quality standard according to SNI 19-7030-2004 which rangef from 10-20. It was caused by the 
nitrogen value $(\mathrm{N})$ which was too small when compared to the carbon value $(\mathrm{C})$.

2. From the results of the analysis that had been conducted on compost produced by WWTP sludge by PT. X, it showed that the variation of compost with ratio of 2: 1: 1: 1 was the most effective while for the ratio of 1: 1: 1 could not meet the quality standards for compost, because the $\mathrm{C} / \mathrm{N}$ ratio value of 26.70 was still above the quality standard compost according to SNI 19-7030-2004 which ranged from 10-20.

3. Observing from the study of technical aspects, that the highest yield of chilli productivity was in chilli plants with additional treatment of compost fertilizer from WWTP sludge by PT.X, with an increase of between $30 \%-42.8 \%$ of chili crop yields with the addition of NPK Mutiara fertilizer treatment with the highest yield of 150 treatments, the addition of compost to area 2.

4. Observing from the economic aspects of the study, it showed that for the use of NPK Mutiara fertilizers, the average cost of fertilizing per $1 \mathrm{Ha}$ of area was Rp. 40,500,000, - and the average yield of Rp. 49,166,700. As for compost, the average cost of fertilizing per 1 hectare of land was Rp. 21.00,000 and the average yield of Rp. 67,500,000.

5. Observing from the aspects of farmers' perceptions on compost produced by WWTP sludge by PT. X, for the level of knowledge of farmers about compost was in the less category (0-15). Meanwhile, the attitude of the farmers regarding compost processed by WWTP sludge was in the sufficient category (8-14).

\section{REFERENCES}

[1] Arikunto, Suharsimi. 2010. Prosedur Penelitian. Jakarta : PT. Rineka Cipta.

[2] Ariyanto. 2009. Correlation Between Safety Knowledge, Attitude and Practice With Safety Manageent Implemetatio In PT. Kereta Api (Persero) Daerah Operasi VI Yogyakarta. Yogy akarta : Universitas Gajah Mada

[3] As'ad, M. 2004. Psikologi Industri. Yogy akarta : Liberti Yogjakarta.

[4] Azwar, Syaifuddin. 2007. Tes Prestasi. Yogyakarta: Pustaka Pelajar Offset.

[5] Azwar, Saifuddin. 2009. Sikap Manusia Teori dan Pengukurannya. Yogy akarta :Pustaka Pelajar Offset.

[6] Cahyadi, Dicky dkk. 2016. Pemanfaatan Limbah Lumpur (Sludge) Wastewater Treatment Plant PT. X Sebagai Bahan Baku Kompos. Makassar : Uviversitas Mercu Buana.

[7] Gunawan, E. 1998. Pengaruh berbagai taraf pengapuran dan kotoran ayam terhadap pertumbuhan bambu betung.
Skripsi. Fakultas Pertanian. Institut Pertanian Bogor, Bogor.

[8] Lingga, P. 2008. Petunjuk Penggunaan Pupuk. Jakarta: Penebar Swadaya.

[9] Taiganides, E. P. 1977. Principles and techniques of animal waste management and utilization. In: organic Recy cling in Asia. FAO Soils Bull, Rome.

[10] Raihan, S., H. S. Simatupang, \& Y. Raihan. 2000. Pengaruh fosfor dan kalium dari bahan organik terhadap hasil jagung di lahan lebak. Dalam: Mustajib, A. Rizal, M. Nurcholis, Soeharto \& S. Wuryani (Eds.). Prosiding Seminar Nasional Pertanian Organik, Yogy akarta.

[11] Musnamar, E.I. 2006. Pembuatan dan Aplikasi Pupuk Organik Padat. Bogor: Seri Agro Tekno Penebar Swadaya.

[12] Dwi, Armaeni Humaerah. 2015. Budidaya Tanaman Cabai keriting (Capsium annuum L.). Jakarta: Universitas UIN Sy arif Hiday atullah.

[13] Dutta, Dhananjoy dan Bandyopadhyay, Protit. 2009. Performance of chickpea (Cicer arietinum L.) to application of phosphorus and bio-fertilizer in laterite soil. Journal Archives of Agronomy and Soil Science. Volume 55, 2009 - Issue 2

[14] Khatoon, Yosefi., Mohammad, Galavi., Mahmod, Ramrodi.,Mousavi and Roholla, Sayed. 2011.Effect of Bio-phosphate and Chemical Phosphorus Fertilizer Accompanied with Micronutrient Foliar Application on Growth, Yield and Yield Components of Maize (Single Cross 704). Australian Journal of Crop Science Volume 5 Issue 2 (2011)

[15] Abdul Nasir., Khan, F. H., Mahmood Riaz., Khan, M. A. 2010. Comparitive study of biogas slurry with farmy ard manure as fertilizer on maize crop. Department of Structures and Environmental Engineering. Vol 22 No. 4. June 2010. Page 297-301

[16] Abubaker, J., Risberg, K. and Pell , M. 2012. Biogas residues as fertilisers - Effects on wheat growth and soil microbial activities. Applied Energy . Volume 99, November 2012, Pages 126-134

[17] Qiu, Meihua., Zhang, Ruifu., Xue, Chao., Zhang, Shusheng.,Li, Shuqing and Zhang, Nan. 2012. Application of bio-organic fertilizer can control Fusarium wilt of cucumber plants by regulating microbial community of rhizosphere soil.2012. Biology and Fertility of Soils October 2012, Volume 48, Issue 7, pp 807-816.

[18] Jeptoo, Agnes., Aguyoh., Joseph N. and Saidi, Mwanarusi. 2013. Improving Carrot Yield and Quality Through the Use of Bioslurry Manure. Canadian Center of Science and Education. Vol 2 No 1. November 2013. Page 311-319

[19] Orskov, Bob., Yongabi, Kenneth., Subedi, Madhu., and Smith, Jo. 2012. Overview of Holistic, Application of Biogas for Small Scale Farmers in Sub-Sarahan Africa. Presentasion reprt for Workshop in Africa. December 2012 